\title{
Patients with chronic kidney disease are not well adhered to dietary recommendations: a cross-sectional study
}

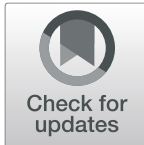

Gebretsadkan Gebremedhin Gebretsadik ${ }^{1 *}$ (D) Zelalem Debebe Mengistu ${ }^{2+}$, Birhanu Worku Molla ${ }^{3 \dagger}$ and Helen Tkuwab Desta ${ }^{1}$

\begin{abstract}
Background: Nutrition and dietary patterns are modifiable factors that can be utilized to prevent or slow the progression of Chronic kidney disease (CKD). Adherence to current dietary recommendations can reduce the incidence, or slow the progression of CKD and reduce mortality. The objectives of this study was to compare the dietary nutrient intake of CKD patients (CKD above stage 3 including hemodialysis) to dietary recommendations and to assess the correlations of those dietary nutrient intakes with each other and with chosen laboratory measurements.
\end{abstract}

Methods: A hospital-based cross-sectional study was conducted among 100 patients with CKD. A consecutive 7 days dietary record supplemented with interviews for data completion was used to assess dietary intake. Recent clinical laboratory measurements were obtained from patients' medical records. The obtained dietary data were analyzed by the Ethiopian food composition database and the nutrisurvey software. Dietary energy and nutrients intake were compared with recommendations for CKD patients.

Results: The dietary energy intake (DEI) of almost all patients was below recommended levels. The average Dietary protein intake (DPI) was above the recommended levels $(0.95 \pm 0.27 \mathrm{~g} / \mathrm{kg} /$ day) for about $60 \%$ of the respondents. Besides, 38\% and only two of the respondents had their dietary phosphorus and potassium intakes above recommended levels, respectively. Estimated Glomerular filtration rate (eGFR) was positively correlated with both total and animal protein intakes while blood levels of creatinine and urea were negatively correlated with animal protein intake.

Conclusion: Patients with CKD are not well adhered to dietary recommendations and some nutrients showed correlation with chosen clinical laboratory measurements. Besides, DEI and DPI were below and above recommended levels, respectively, for most patients. Besides, more than one-third of the participants had phosphorus intakes above recommendation. These non-optimal dietary nutrient intakes may contribute to fast clinical deterioration and mortality.

Keywords: Dietary intake, Dietary recommendations, CKD, Dietary protein, Dietary energy, Ethiopia

\footnotetext{
* Correspondence: gere2023@gmail.com

†Zlalem Debebe Mengistu and Birhanu Worku Molla contributed equally to

this work.

${ }^{1}$ Department of Nutrition and Dietetics, School of Public Health, College of

Health Sciences, Mekelle University, Mekelle, Ethiopia

Full list of author information is available at the end of the article
}

(c) The Author(s). 2020 Open Access This article is distributed under the terms of the Creative Commons Attribution 4.0 International License (http://creativecommons.org/licenses/by/4.0/), which permits unrestricted use, distribution, and reproduction in any medium, provided you give appropriate credit to the original author(s) and the source, provide a link to the Creative Commons license, and indicate if changes were made. The Creative Commons Public Domain Dedication waiver (http://creativecommons.org/publicdomain/zero/1.0/) applies to the data made available in this article, unless otherwise stated. 


\section{Background}

Recently, the prevalence of CKD has increased exponentially and is costing developed countries a huge proportion of health care finances, while significantly contributing to morbidity, mortality, and decreased life expectancy in the developing ones [1]. The prevalence of CKD among diabetic patients in southern Ethiopia was 18.2 and $23.8 \%$ when defined according to the Modification of diet in renal disease (MDRD) and CockcroftGault eq. (C-G) equations, respectively [2].

Dietary therapy has historically been used in the management of CKD and adherence to current dietary guidelines can reduce the incidence, or slow the progression of CKD and reduce mortality [3]. General goals of dietetic management in CKD patients include preserving kidney function, maintaining optimal nutritional status, reducing uremic symptoms, postponing the need for dialysis and aiming for a healthy initiation of dialysis (for Predialysis patients), correcting metabolic imbalances, preventing complications, and improving quality of life and patient-centered outcomes $[4,5]$.

Steiber found that less than a quarter of the patients with chronic renal failure met $75 \%$ or more of their energy and protein needs as patients in different stages were involved in the study [6]. In addition, Duenhas et al. concluded that energy and protein intake in a group of predialysis individuals was too low $(24.9 \pm 8.2$ $\mathrm{kcal} / \mathrm{kg} /$ day and $0.95 \pm 0.36 \mathrm{~g} / \mathrm{kg} /$ day respectively) [7].

The World health organization (WHO) recommends $0.83 \mathrm{~g}$ of protein $/ \mathrm{Kg}$ of body weight as the safe level for healthy adults [8]. Low protein diet (LPD), which contains $0.8 \mathrm{~g}$ (or $0.6 \mathrm{~g}$ ) of Protein $/ \mathrm{Kg}$ of body weight according to the recommendations, had been proven to delay the progression of CKD by lengthening the predialysis phase and to reduce renal causes of mortality [9]. In practice, however, patients following this LPD often reduce the amount of consumed food, which creates difficulties in achieving the right balance of energy and other nutrients and makes it very difficult to prevent protein catabolism and subsequent protein-energy malnutrition [10].

In Ethiopia, CKD patients receive dietary advice from physicians and nurses because there is a lack of trained dietitians. Although there are some studies that assessed the prevalence of CKD, none tried to assess the adherence of these patients to dietary recommendations. Therefore, the aim of this study is to compare the dietary nutrient intakes of patients with CKD to recommendations and to assess the correlations of these nutrient intakes swith chosen clinical laboratory measurements.

\section{Methods}

\section{Study setting, design, and sample size}

This hospital-based cross-sectional study was carried out from January to March 2018 in two selected hospitals (St.
Paul's hospital millennium medical college (SPHMMC) and Sante medical center) with CKD outpatient clinics. Data were collected from purposely taken 100 CKD outpatients (patients on follow-up) (including hemodialysis patients) who were selected from both hospitals proportional to their total CKD population (68 participants from SPHMMC and 32 participants from santé medical center).

\section{Inclusion criteria}

CKD Patients in 3rd - 5th stage with eGFR $<60 \mathrm{ml} / \mathrm{min} /$ $1.73 \mathrm{~m} 2$, patients without previous dietary intervention received from a dietitian/nutritionist, and patients diagnosed at least 6 months before the study were included.

\section{Exclusion criteria}

Patients diagnosed less than 6 months before the study, those with speaking difficulties, and those unwilling to participate were excluded.

At every follow-up encounter, patients are seen by their doctors and nurses. Patients who came for follow up on the data collection period and met the criteria were approached and included if they give consent.

\section{Data collection procedures and quality improvement}

Sociodemographic data were collected using structured interviewer-administered questionnaire. Weight was measured by a scale with a maximum capacity of $150 \mathrm{~kg}$ and accuracy of $0.1 \mathrm{~kg}$ and was calibrated after each measurement. Height was measured in standing position in stadiometer but for those confined to bed arm span was used. Body mass index (BMI) was calculated using weight and height.

Biochemical data including eGFR, Creatinine, Urea, phosphate, and other chosen biological indicators (blood levels) were obtained from patients' medical records. The last three (or two) measurements were obtained from the medical charts and an average was taken as final measurement.

A consecutive seven-day dietary record was obtained from each participant. Before data collection started, participants were instructed about the principles of completing the dietary record, the necessity for an accurate and thorough recording of all food products and beverages consumed, and were provided with food picture models to help them estimate portion sizes. Participants were interviewed at the time of submission of the dietary records to get more complete dietary intake data.

Training of the data collectors, translation of the data collection tool into the local language (Amharic), and pretest of the tool in $10 \%$ of the participants were done before data collection started to ensure the quality of the data. 


\section{Statistical analysis}

The Ethiopian food composition table and nutrisurvey software were used to analyze the dietary data, and SPSS version 20 was utilized for further statistical analysis.

Energy and nutrients intake of participants were compared to recommendations for CKD patients [11, 12] or to recommendations for healthy individuals when they were not established [8] (Table 1). Recommended Daily Allowance (RDA) was used to assess the adequacy of nutrients, and Adequate Intake (AI) level was used for those nutrients without an established RDA.

Mean \pm standard deviation for normally distributed data and Median \pm Interquartile range for non-normally distributed data are used to present findings. ShapiroWilk test was used to check the distribution of the analyzed variables. In order to characterize correlations among factors, Pearson's and Spearman's correlation were utilized for normal and non-normal distribution, respectively.

Table 1 Dietary energy and nutrients recommendations for CKD patients

\begin{tabular}{|c|c|}
\hline Nutrients & Recommended intake \\
\hline \multirow{2}{*}{$\begin{array}{l}\text { Energy }[\mathrm{Kcal}(\mathrm{KJ}) / \mathrm{Kg} \text { of } \\
\text { body weight] }]^{\mathrm{a}, \mathrm{b}}\end{array}$} & 146 (35) - For age below 60 \\
\hline & $126-146(30-35)$ - For age above 60 \\
\hline \multirow{2}{*}{$\begin{array}{l}\text { Total Protein }[\mathrm{g} / \mathrm{Kg} \text { of } \\
\text { body weight] }\end{array}$} & $0.6^{1} / 0.8^{c}-$ Predialysis \\
\hline & $1.1-1.2^{\mathrm{a}}$-Dialysis \\
\hline $\begin{array}{l}\text { Animal protein [\% of total } \\
\text { protein intake] }\end{array}$ & $\geq 50$ \\
\hline Fat[\% of energy $]^{a}$ & $25-35$ \\
\hline Carbohydrate [\% of energy $]^{a}$ & $45-60$ \\
\hline Fiber $[\mathrm{g}]^{\mathrm{a}}$ & $20-30$ \\
\hline Sodium [mg]1 & 2400 \\
\hline Potassium $[\mathrm{mg}]^{\mathrm{a}, \mathrm{c}}$ & 4700 \\
\hline \multirow[t]{2}{*}{ Phosphorus [mg] } & 800-1000- For Predialysis patients ${ }^{a}$ \\
\hline & 1000-1400- For Dialysis patients ${ }^{b}$ \\
\hline \multirow[t]{3}{*}{$\operatorname{Iron}[\mathrm{mg}]^{\mathrm{c}}$} & 8 - For men \\
\hline & 18- For women 19-50 \\
\hline & 8 - For women $>50$ \\
\hline \multirow[t]{2}{*}{ Vitamin $\mathrm{A}[\mu \mathrm{g}]^{\mathrm{C}}$} & 900- for Men \\
\hline & 700- For women \\
\hline \multirow[t]{3}{*}{ Vitamin D $[\mu \mathrm{g}]^{\mathrm{a}, \mathrm{c}}$} & 5- For age $19-50$ years \\
\hline & 10 -for age $51-70$ years \\
\hline & 15- For age above 70 years \\
\hline
\end{tabular}

${ }^{a}$ Kopple, J. D. (2001) [12]. National kidney foundation K/DOQI clinical practice guidelines for nutrition in chronic renal failure. American Journal of Kidney Diseases, 37(1), S66-S70

bJames, G., \& Jackson, H. (2003) [11]. European guidelines for the nutritional care of adult renal patients. EDTNA/ERCA Journal, 29(1), 23-43

'WHO, J. (2007) [8]. Protein and amino acid requirements in human nutrition. World health organization technical report series (935), 1

\section{Results}

In this study, for which the response rate was $100 \%$, among the total 100 respondents, the majority (79\%) were males. The age of the respondents averaged $47.76 \pm 12.98$ years, and most (96) were less than 70 years of age. The Sociodemographic characteristics of the respondents are shown below (Table 2).

The findings confirmed that $90(90 \%)$ of the respondents were on dialysis, and $10(10 \%)$ were not on dialysis. About 59(59\%) and 39 (39\%) were hypertensive and diabetic, respectively.

The average BMI of the respondents was $22.91 \pm 3.46$ $\mathrm{kg} / \mathrm{m}^{2}$. The average creatinine, eGFR, and urea levels were $2.9 \pm 1.87 \mathrm{mg} / \mathrm{dl}, 33.4 \pm 13.04 \mathrm{ml} / \mathrm{min} / 1.73 \mathrm{~m} 2$, and $68.3 \pm 22.21 \mathrm{mg} / \mathrm{dl}$ respectively (Table 3 ).

The average DEI was $1394.62 \pm 212.61 \mathrm{Kcal}(5835.07 \pm$ $889.57 \mathrm{KJ} /$ /day. The energy intake per body weight

Table 2 Sociodemographic characteristics of CKD patients in two selected hospitals in Addis Ababa, Ethiopia, 2018

\begin{tabular}{|c|c|c|}
\hline \multicolumn{2}{|l|}{ Characteristics } & \multirow{2}{*}{$\begin{array}{l}\text { Frequency } \\
79(79 \%)\end{array}$} \\
\hline Sex & Male & \\
\hline & Female & $21(21 \%)$ \\
\hline \multirow[t]{5}{*}{ Age } & $<40$ & $30(30 \%)$ \\
\hline & $41-49$ & $23(23 \%)$ \\
\hline & $50-59$ & $25(25 \%)$ \\
\hline & $60-69$ & $18(18 \%)$ \\
\hline & $>=70$ & $4(4 \%)$ \\
\hline \multirow[t]{2}{*}{ Residence } & Urban & 90 (90\%) \\
\hline & Rural & $10(10 \%)$ \\
\hline \multirow[t]{4}{*}{ Religion } & Orthodox & $63(63 \%)$ \\
\hline & Muslim & $29(29 \%)$ \\
\hline & Protestant & $7(7 \%)$ \\
\hline & Catholic & $1(1 \%)$ \\
\hline \multirow[t]{4}{*}{ Marital status } & Single & $29(29 \%)$ \\
\hline & Married/living together & $60(60 \%)$ \\
\hline & Divorced & $8(8 \%)$ \\
\hline & Widowed & $3(3 \%)$ \\
\hline \multirow[t]{4}{*}{ Educational level } & No formal education & $7(7 \%)$ \\
\hline & Primary & $15(15 \%)$ \\
\hline & Secondary & $28(28 \%)$ \\
\hline & More than secondary & $50(50 \%)$ \\
\hline \multirow[t]{7}{*}{ Occupation } & Professional/technical & $32(32 \%)$ \\
\hline & Clerical & $8(8 \%)$ \\
\hline & Sales and services & 38 (38\%) \\
\hline & Skilled manual & $1(1 \%)$ \\
\hline & Unskilled manual & $2(2 \%)$ \\
\hline & Agriculture & $5(5 \%)$ \\
\hline & Other & 14 (14\%) \\
\hline
\end{tabular}


Table 3 Anthropometric and laboratory measurements of CKD patients in two selected hospitals in Addis Ababa, Ethiopia, 2018

\begin{tabular}{lll}
\hline Characteristics & Mean & SD \\
\hline Age $[$ Years] & 47.76 & 12.98 \\
Weight $[\mathrm{Kg}]$ & 64.73 & 11.31 \\
Height $[\mathrm{m}]$ & 1.67 & 0.06 \\
BMI $[\mathrm{Kg} / \mathrm{m} 2]$ & 22.91 & 3.46 \\
Creatinine $[\mathrm{mg} / \mathrm{dl}]$ & 2.9 & 1.87 \\
GFR $[\mathrm{ml} / \mathrm{min} / 1.73 \mathrm{~m} 2]$ & 33.4 & 13.04 \\
Urea $[\mathrm{mg} / \mathrm{dl}]$ & 68.3 & 22.21 \\
Potassium $[\mathrm{mg} / \mathrm{dl}]$ & 4.6 & 0.59 \\
Hemoglobin $[\mathrm{mg} / \mathrm{dl}]$ & 10.6 & 0.81 \\
Albumin $[\mathrm{mg} / \mathrm{dl}]$ & 3.4 & 0.35 \\
Phosphate $[\mathrm{mM} /]$ & 4.6 & 1.02 \\
\hline
\end{tabular}

averaged $22.15 \pm 5.01 \mathrm{Kcal} / \mathrm{Kg}$. The average total, animal, and plant protein values of the diet were $0.95 \pm 0.27 \mathrm{~g} /$ $\mathrm{kg}, 0.45 \pm 0.19 \mathrm{~g} / \mathrm{kg}$, and $0.5 \pm 0.12 \mathrm{~g} / \mathrm{kg}$ of body weight, respectively (Table 4).

Carbohydrates provided the majority of the DEI, $(65.15 \pm 6.7 \%)$ ranging $50-79 \%$. The findings confirmed that almost all respondents had their daily energy intakes below recommended levels (only 3 respondents fulfilled the recommendation). The other interesting finding is that $62(62 \%)$ respondents had their total protein intakes on or above recommended levels with the animal protein intake lower than the recommendations

Table 4 Daily average energy value and nutrients content of the diet of CKD patients in two selected hospitals in Addis Ababa, Ethiopia, 2018

\begin{tabular}{|c|c|c|}
\hline Nutrients & Mean & SD \\
\hline Energy [Kcal (KJ)] & $1394.62(5835.07)$ & $212.61(889.57)$ \\
\hline Energy [Kcal/kg] & 22.15 & 5.01 \\
\hline Carbohydrate [g] & 243.99 & 45.65 \\
\hline Total protein [g] & 59.75 & 12.81 \\
\hline Animal protein $[g]$ & 28.12 & 10.24 \\
\hline Plant protein [g] & 31.62 & 5.70 \\
\hline Protein per weight [g/kg] & 0.95 & 0.27 \\
\hline Fat $[g]$ & 32.172 & 8.45 \\
\hline Sodium [mg] & 1925.5 & 644.15 \\
\hline Potassium [mg] & 1854.5 & 364.34 \\
\hline Phosphorus [mg] & 947.86 & 209.46 \\
\hline Iron [mg] & 45.56 & 12.15 \\
\hline Vitamin D $[\mu \mathrm{g}]$ & 1.48 & 0.58 \\
\hline Fluid [ml] & 1121.1 & $(218.2-2121.4)^{a}$ \\
\hline Fibre [g] & 13.59 & 5.39 \\
\hline
\end{tabular}

an case of nonparametric variables - median, minimum and maximum values are presented in about two-thirds $(64 \%)$ of the analyzed respondents (Table 5).

Average DEI was strongly positively correlated with DPI $(\mathrm{r}=+0.74, p<0.001)$. DPI was also positively correlated with animal protein, plant protein, and phosphorus intakes (Table 6).

eGFR was positively weakly correlated with both total $(\mathrm{r}=+0.236, p=0.018)$ and animal $(\mathrm{r}=+0.30, p=0.002)$ protein intakes, but not with plant protein intake. Blood levels of creatinine and urea had a weak negative correlation with animal protein intake $(\mathrm{r}=-0.265, p=0.008$ and $\mathrm{r}=-0.242, p=0.015$, respectively) but no correlation with total and plant protein intakes. Besides, blood levels of phosphate showed no correlation with protein and phosphorus intake. (Table 7).

\section{Discussion}

The findings of this study confirmed that almost all respondents had their daily energy intakes below recommended levels (only 3 respondents fulfilled the recommendation). Similarly, in other studies, only two individuals met the daily dietary energy recommendations [10] and only $15 \%$ of patients reached $75 \%$ of their energy requirements [6]. Additionally, Shahar et al. found that the mean caloric intake $(1683.9+/ 546.9 \mathrm{kcal} /$ day) for Haemodialysis (HD) patients deviated almost $20 \%$ below guidelines [13]. These similarities might be justified by the fact that all CKD patients have problems getting the right amount of dietary energy due to various factors including reduction in appetite.The average total protein intake in this presented research was $0.95 \mathrm{~g} / \mathrm{kg}$ of body weight. This is higher than the average DPI in another study in which it was $0.85 \mathrm{~g} / \mathrm{kg}$ of ideal body weight [10]. This may be reasoned out by the fact that the respondents in the later study were only predialysis patients, who usually limit their protein intake more than patients on dialysis.

Around $60 \%$ of the respondents in this study had their total protein intakes above recommended levels. This is a little bit different from a study done in Taiwan in which DPIs were significantly higher than the recommended levels in less than half of the respondents (47.2\%) [14]. This variation could be because respondents in this presented research have never received counseling from a dietitian but a subset of those in the Chen et al., study received counseling from registered dietitians in the hospital they attend. Moreover, this difference can be attributed to the fact that protein intake goals set by the dietitians in the hospital, which were different from those set by National kidney foundation/Kidney disease outcomes quality initiative (NKF/ KDOQI) intake goals, were used because the dietitians considered the patient's current intake status. 
Table 5 Daily energy and nutrients intake compared to recommendations, of CKD patients in two selected hospitals in Addis Ababa, Ethiopia, 2018

\begin{tabular}{|c|c|c|c|}
\hline & $\%$ of respondents characteri & & \\
\hline & Below recommended level & On recommended level & Above recommended level \\
\hline Energy & 97 & 1 & 2 \\
\hline Carbohydrate & 0 & 27 & 73 \\
\hline Fat & 87 & 13 & 0 \\
\hline Protein & 38 & 2 & 60 \\
\hline Animal protein & 64 & 36 & 0 \\
\hline Sodium & 66 & $20^{\mathrm{a}}$ & 14 \\
\hline Potassium & 98 & $0^{a}$ & 2 \\
\hline Phosphorus & 26 & 36 & 38 \\
\hline Iron & 0 & $0^{a}$ & 100 \\
\hline Vitamin D & 100 & $0^{a}$ & 0 \\
\hline Fibre & 87 & 13 & 0 \\
\hline
\end{tabular}

${ }^{a}$ recommended value $\pm 10 \%$

About two-thirds (64\%) of the analyzed respondents had animal protein intakes lower than the recommendations. However, it is recommended that greater than half of the protein intake should be of a high biologic value such as proteins in eggs, fish, poultry, meat, and dairy products because of the presence of essential amino acids [15]. Nevertheless, higher animal protein consumption, including red meat [16], is associated with rendering the kidneys to excrete a higher acid load as compared to higher dietary plant protein intake [17].

In this presented research, only two respondents had their daily dietary potassium intakes above recommendations. In a 5 years cohort study, a higher dietary

Table 6 Correlation of total, animal, and plant protein intake with Energy and nutrients content of the diet of CKD patients in two selected hospitals in Addis Ababa, Ethiopia, 2018

\begin{tabular}{|c|c|c|c|c|c|c|}
\hline \multirow[t]{2}{*}{ Nutrients } & \multicolumn{2}{|c|}{ Total protein } & \multicolumn{2}{|c|}{ Animal protein } & \multicolumn{2}{|c|}{ Plant protein } \\
\hline & $\mathrm{R}$ & $P$ & $R$ & $P$ & $\mathrm{R}$ & P \\
\hline Energy & $0.737^{* *}$ & 0.000 & $0.577^{* *}$ & 0.000 & $0.602^{* *}$ & 0.000 \\
\hline Carbohydrate & $0.309^{* *}$ & 0.002 & -0.145 & 0.150 & $0.444^{* *}$ & 0.000 \\
\hline Fat & $0.489^{* *}$ & 0.000 & $0.596^{* *}$ & 0.000 & 0.110 & 0.275 \\
\hline Total Protein & - & - & $0.574^{* *}$ & 0.000 & $0.627^{* *}$ & 0.000 \\
\hline Animal protein & $0.574^{* *}$ & 0.000 & - & - & $0.315^{* *}$ & 0.001 \\
\hline Plant protein & $0.627^{* *}$ & 0.000 & $0.315^{* *}$ & 0.001 & - & - \\
\hline Fibre & $0.406^{* *}$ & 0.000 & $0.221^{*}$ & 0.027 & $0.552^{* *}$ & 0.000 \\
\hline Sodium & 0.050 & 0.625 & -0.142 & 0.158 & $0.258^{* *}$ & 0.01 \\
\hline Potassium & $0.370^{* *}$ & 0.000 & 0.168 & 0.095 & $0.535^{* *}$ & 0.000 \\
\hline Phosphorus & $0.741^{* *}$ & 0.000 & $0.652^{* *}$ & 0.000 & $0.202^{*}$ & 0.044 \\
\hline Iron & -0.097 & 0.339 & $-0.244^{*}$ & 0.014 & 0.170 & 0.091 \\
\hline Vitamin D & -0.068 & 0.498 & -0.126 & 0.212 & 0.075 & 0.457 \\
\hline
\end{tabular}

${ }^{*}$ Correlation statistically significant at $\mathrm{P} \leq 0.01$

${ }^{*}$ Correlation statistically significant at $P \leq 0.05$ potassium intake was associated with increased death risk in HD patients, even after adjustments for other nutrient intakes [18]. Conversely, during earlier stages of CKD a diet high in potassium, which is usually low in sodium, may slow the progression of the disease by lowering blood pressure [19]. A small study suggested that the dietary approach to stop hypertension (DASH) diet may be a valuable, non-pharmacologic strategy for blood pressure control in individuals with CKD. However, this needs to be confirmed in larger sample size in order to be recommended [20].

In this presented study, respondents consuming less protein were simultaneously characterized by a lower intake of energy and most other nutrients. Similarly, in other research, CKD patients in highest baseline DPI and DEI quartiles had 4.11-fold (95\% confidence interval: 2.79-6.05) higher odds of having protein energy wasting syndrome at month 12 [21]. These similarities may happen as a result of patients limiting the quantity of all consumed foods in an attempt to limit the level of protein in the diet. It is important that for HD patients an adequate energy intake is required to achieve positive nitrogen balance and individualized advice on suitable dietary sources of protein should be delivered by dietitian/nutrition advisors [11, 15].

Respondents with higher protein intake also had higher dietary phosphorus intake. Similarly, a review showed that there is a correlation between dietary intakes of protein and phosphorus [22]. In this study, however, DPI (or dietary phosphorus) was not correlated with serum phosphate levels. This is supported by another study which described that a high protein (and high phosphorus) diet does not always correlate with increased serum phosphate levels [23]. The difference in bioavailability of phosphorus from foods items may be 
Table 7 Correlation of creatinine, eGFR, Urea, blood phosphate, and albumin levels with Energy and nutrients content of the diet of CKD patient in two selected hospitals in Addis Ababa, Ethiopia, 2018

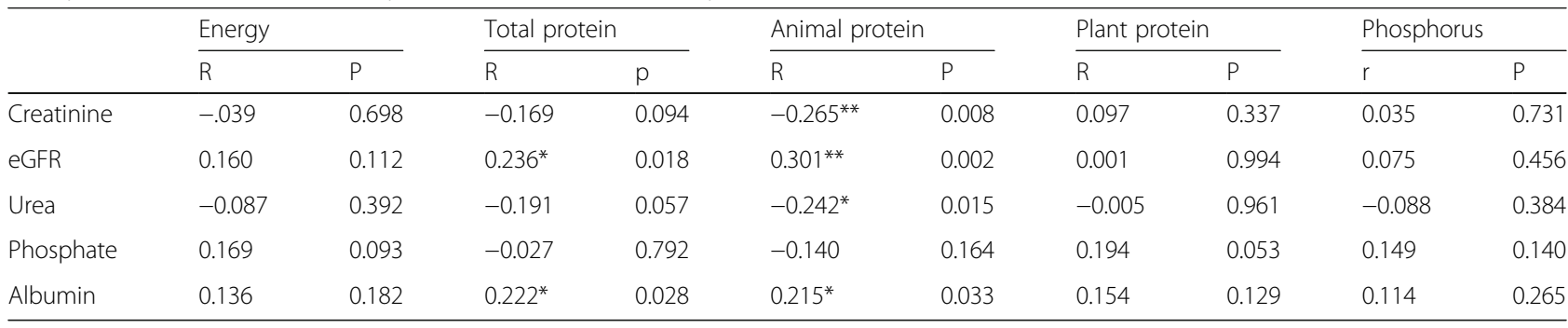

${ }^{* *}$ Correlation statistically significant at $P \leq 0.01$

* Correlation statistically significant at $P \leq 0.05$

the reason for this. Consuming a greater amount of protein from plants foods and reducing taking foods containing the inorganic phosphate which is readily absorbable and highly contributes to dietary phosphate load will be beneficial in the CKD population [24].

In this presented study, eGFR was significantly positively correlated with both total and animal protein intakes, but not with plant protein intake. Blood levels of creatinine and urea were also significantly negatively correlated with animal protein intake but not with total or plant protein intake. This is supported by other studies. A spontaneous decrease in energy and protein intake followed a decline in renal function in patients with no previous dietary intervention [7]. Similarly, patients with more advanced disease were characterized by significantly lower protein intake, which was associated with limiting animal protein [10]. These similarities in the findings imply the fact that patients reduce animal products, not plant products, which they think make a large source of protein. This may lead to a deficiency of essential amino acids and the risk of acquiring malnutrition. In contrast, other studies showed that lower energy and higher protein intakes than recommended levels may be associated with lowering renal function markers [14, 25] [26]. These studies mostly involved advanced CKD patients and support the current nutrition practice guidelines on providing adequate energy and optimal protein.

This study has some limitations. First, there may be a possibility of selection bias as the 100 study participants were selected purposely (non-random sampling). This was done in order to get an extensive dietary intake data (7 days dietary record) from each patient. However, this might have created problems with the generalizability of the findings, though. Second, since data were collected at one point in time, this study can't show any cause and effect relationship between variables. In order to draw more reliable findings and conclusions, similar studies with stronger methodologies should be done in the future. Third, Dietary records might not provide an exact estimation of dietary nutrient intake. This is because respondents might have problems with accurately quantifying food portions and some might have changed their eating patterns which might distort the findings and lead to invalid conclusions. This limitation would be overcome if future researchers apply a more objective and stronger dietary intake assessment method to get accurate nutrient intake data and plausible findings.

\section{Conclusion}

Patients with Chronic kidney disease are not well adhered to current dietary recommendations. Respondents consuming less total, animal, or plant protein were simultaneously characterized by lower intake of energy and most other nutrients. Additionally, eGFR was correlated with both total and animal protein intakes, whereas blood levels of creatinine and urea were significantly negatively correlated with animal protein intake but not with total protein, plant protein, or phosphorus intakes. The findings imply that non-optimal dietary nutrient intake may contribute to fast clinical deterioration and mortality in CKD patients. Finally, the findings imply that there is an urgent need of the deployment of dietitians in hospitals that can provide appropriate counselling for patients with CKD.

\section{Abbreviations}

Al: Adequate intake; BMI: Body mass index; CG: Cockcroft Gault; CKD: Chronic kidney disease; DEl: Dietary energy intake; DI: Decilitre; DPI: Dietary protein intake; eGFR: Estimated glomerular filtration rate; G/Kg: Gram/Kilogram; IRB: Institutional review board; Kcal: Kilo calories; KDOQI: Kidney disease outcomes quality initiatives; KJ: Kilo joules; LPD: Low protein diet; MDRD: Modification of diet in renal disease; Mg: Milligrams; NKF: National kidney foundation; RDA: Recommended daily allowance; SPHMMC: Saint Paul's Hospital Millenium Medical College; SPSS: Statistical package for social sciences; WHO: World health organization

\section{Acknowledgments}

Our sincere gratitude goes to Dr. Kaleab Baye (Associate professor) for his invaluable input in the process of conducting this study. We would also like to recognize the contributions of everyone involved from the design to the final write up of this document.

\section{Authors' contributions}

GG significantly contributed to the conceptualization and design of the study, acquisition, analysis, and interpretation of data and drafted the manuscript. ZD and BW were involved in critically revising the study design and the manuscript. HT participated in the data collection process and write up of draft manuscript. All authors read and approved the final manuscript. 
Funding

None.

\section{Availability of data and materials}

The datasets used and/or analyzed during the current study are available from the corresponding author on reasonable request.

\section{Ethics approval and consent to participate}

Written consent was obtained from each participant and ethical approval for the research was obtained from Addis Ababa University, College of natural and computational sciences, Institutional review board committee (IRB number: IRB/032/2018).

\section{Consent for publication}

Not applicable.

\section{Competing interests}

The authors declare that they have no competing interests.

\section{Author details}

'Department of Nutrition and Dietetics, School of Public Health, College of Health Sciences, Mekelle University, Mekelle, Ethiopia. ${ }^{2}$ Center for Food Science and Nutrition, College of Natural and Computational Sciences, Addis Ababa University, Addis Ababa, Ethiopia. ${ }^{3}$ Department of Nephrology, Saint Paul's Hospital Millennium Medical College, Addis Ababa, Ethiopia.

Received: 9 August 2019 Accepted: 10 February 2020

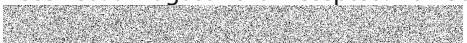

\section{References}

1. Arogundade FA, Barsoum RS. CKD prevention in sub-Saharan Africa: a call for governmental, nongovernmental, and community support. Am J Kidney Dis. 2008;51:515

2. Fiseha T, Kassim M, Yemane T. Prevalence of chronic kidney disease and associated risk factors among diabetic patients in southern Ethiopia. Am J Health Res. 2014;2(4):216-21.

3. Dunkler, D., et al., Dietary risk factors for incidence or progression of chronic kidney disease in individuals with type 2 diabetes in the European Union. 2015.

4. Ayli MD, et al. Effect of low-protein diet supplemented with keto acids on progression of disease in patients with chronic renal failure. Nephron. 2000; 84(3):288-9

5. Chan M, Kelly J, Tapsell L. Dietary modeling of foods for advanced CKD based on general healthy eating guidelines: what should be on the plate? Am J Kidney Dis. 2016;69(3):436.

6. Steiber AL. Clinical indicators associated with poor oral intake of patients with chronic renal failure. J Ren Nutr. 1999:9(2):84-8.

7. Duenhas $\mathrm{M}$, et al. Influence of renal function on spontaneous dietary intake and on nutritional status of chronic renal insufficiency patients. Eur J Clin Nutr. 2003;57(11):1473-8

8. WHO J. Protein and amino acid requirements in human nutrition. World Health Organ Tech Rep Ser. 2007;935:1.

9. Conditions, N.C.C.f.C, Chronic Kidney Disease: National Clinical Guideline for Early Identification and Management in Adults in Primary and Secondary Care. 2008.

10. Wlodarek D, Glabska D, Rojek-Trebicka J. Assessment of diet in chronic kidney disease female predialysis patients. Ann Agric Environ Med. 2014;21:4.

11. James $G$, Jackson $H$. European guidelines for the nutritional care of adult renal patients. EDTNA ERCA J. 2003;29(1):23-43.

12. Kopple JD. National kidney foundation $\mathrm{K} / \mathrm{DOQ}$ clinical practice guidelines for nutrition in chronic renal failure. Am J Kidney Dis. 2001;37(1):S66-70.

13. Shahar D, Barakat RAS, Haviv Y. Determinants of ESRD patients\&\#x2019; nutritional status and their dietary intake quality, should we re-consider some recommendations? Clin Nutr. 2018:37:S238.

14. Chen $M-E$, et al. Correlations of dietary energy and protein intakes with renal function impairment in chronic kidney disease patients with or without diabetes. Kaohsiung J Med Sci. 2017;33(5):252-9.

15. Zha Y Qian Q. Protein Nutrition and Malnutrition in CKD and ESRD. Nutrients. 2017;9(3):208.
16. Mafra D, et al. Red meat intake in chronic kidney disease patients - two sides of the coin. Nutrition. 2017:46:26.

17. Adeva MM, Souto G. Diet-induced metabolic acidosis. Clin Nutr. 2011;30(4): $416-21$

18. Noori N, et al. Dietary potassium intake and mortality in long-term hemodialysis patients. Am J Kidney Dis. 2010;56(2):338-47.

19. Adrogue HJ, Madias NE. Sodium and potassium in the pathogenesis of hypertension. N Engl J Med. 2007;356(19):1966-78.

20. Tyson CC, et al. Impact of kidney function on effects of the dietary approaches to stop hypertension (Dash) diet. J Hypertens. 2014;3:1.

21. Beddhu S, et al. Associations of dietary protein and energy intakes with protein-energy wasting syndrome in hemodialysis patients. Kidney Int Rep. 2017:2(5):821-30

22. Kalantar-Zadeh $\mathrm{K}$, et al. Understanding sources of dietary phosphorus in the treatment of patients with chronic kidney disease. Clin J Am Soc Nephrol. 2010;5(3):519-30.

23. Kloppenburg WD, et al. Effect of prescribing a high protein diet and increasing the dose of dialysis on nutrition in stable chronic haemodialysis patients: a randomized, controlled trial. Nephrol Dial Transplant. 2004;19(5): 1212-23.

24. Snelson, et al. Stirring the Pot: Can Dietary Modification Alleviate the Burden of CKD? Nutrients. 2017:9(3):265.

25. Huang $\mathrm{M}-\mathrm{C}$, et al. Inadequate energy and excess protein intakes may be associated with worsening renal function in chronic kidney disease. J Ren Nutr. 2008;18(2):187-94.

26. Metzger $\mathrm{M}$, et al. Association of a low-Protein Diet with Slower Progression of CKD. Kidney Int Rep. 2018;3(1):105-14.

\section{Publisher's Note}

Springer Nature remains neutral with regard to jurisdictional claims in published maps and institutional affiliations.
Ready to submit your research? Choose BMC and benefit from:

- fast, convenient online submission

- thorough peer review by experienced researchers in your field

- rapid publication on acceptance

- support for research data, including large and complex data types

- gold Open Access which fosters wider collaboration and increased citations

- maximum visibility for your research: over $100 \mathrm{M}$ website views per year

At BMC, research is always in progress.

Learn more biomedcentral.com/submissions 